DOI: $10.15421 / 4219032$

УДК 539.3

П. З. Луговой' д-р техн. наук, Т. В. Гребенюк², канд. техн. наук

\title{
ВЗАИМОДЕЙСТВИЕ УДАРНЫХ ВОЛН С ГОРНЫМИ ВЫРАБОТКАМИ
}

Теоретическое моделирование взаимодействия ударных волн с горными выработками весьма актуально в горном деле. Особая роль в задачах исследования действия ударных волн, вызванных технологическими взрывами или горными ударами, принадлежит лучевому методу. С его помощью исследовано напряженное состояние горных выработок при воздействии на них взрывныХ волн. Предложен динамический критерий прочности для определения устойчивости горных выработок. На конкретном примере показана эффективность разработанной методики.

Ключевые слова: горные выработки, ударные волны, лучевой метод, прочностная устойчивость, численные результаты.

Введение. Теоретическое моделирование явлений распространения ударных волн весьма актуально в горном деле при определении прочности горных пород в окрестностях горных выработок под воздействием волн, вызванных технологическими взрывами и горными ударами [11 - 14]. В теории упругости [3] ударными волнами называют волны, перед фрронтами которых среда находится в ненапряженном состоянии, за фрронтом напряжения имеют конечные величины, а на поверхности фронта они терпят разрыв непрерывности. В линейной теории упругости движущиеся фронты разрывов напряжений называются слабыми ударными волнами. Они переносят на фронте скачок давления и имеют скорость звука $[8,9]$. С помощью таких динамических моделей можно описывать явления распространения и трансформирования в горных массивах волн, вызванных технологическими взрывами или горными ударами. Особая роль в задачах исследования описанных выше ударных волн принадлежит лучевому методу, используемому в волновой теории геометрической оптики $[1,6,10,15]$.

Постановка задачи. Для описания распространения разрывов (скачков) производных полевой фрункции, воспользуемся волновым уравнением для скалярного потенциала $\varphi$

$$
\nabla^{2} \varphi-\frac{1}{c^{2}} \frac{\partial^{2} \varphi}{\partial t^{2}}=0
$$

где искомая фрункция $\varphi$ в окрестности фронта волны представляется в виде ряда Тэйлора по лучевой координате 


$$
\varphi(\vec{x}, t)=\sum_{m=0}^{\infty} \varphi_{m}(\vec{x}) \frac{[t-\tau(\vec{x})]^{m}}{m !} .
$$

Здесь $\vec{x}$ - радиус-вектор; функция $\tau(\vec{x})$ описывает распространение фронта с помощью уравнения $t-\tau(\vec{x})=0$, удовлетворяющегося на его поверхности. При этом лучи оказываются нормальными к поверхности фрронта.

В результате подстановки (2) в (1) получим уравнение, определяющее длину пути, прошедшего волной

$$
(\nabla \tau)^{2}=1 / c^{2},
$$

где $c$ - скорость распространения возмущения в данной горной породе.

Система уравнений переноса примет вид

$$
2(\nabla \tau) \cdot\left(\nabla \varphi_{k}\right)+\varphi_{k} \nabla^{2} \tau=\nabla^{2} \varphi_{k-1} \quad(k=0,1,2,3, \ldots) .
$$

Она используется для определения функций $\varphi_{k}(k=0,1,2, \ldots)$. При этом необходимо иметь в виду, что $\varphi_{k}=0$ в случае $k<0$.

Положение фронта ударной волны определяется решением уравнения (1). Разрыв функции нестационарного поля на поверхности фронта описывается нулевым членом ряда (2)

$$
\left.\varphi(\vec{x}, t)\right|_{t=\tau}=\varphi_{0}(\vec{x}),
$$

который определяется из первого уравнения системы (4) независимо от решения остальных уравнений.

В [10] уравнения движения однородной анизотропной среды при распространении слабых ударных волн представлены в виде:

$$
\sum_{k, p, q=1}^{3} \frac{c_{i k, p q}}{\rho} \frac{\partial^{2} u_{q}}{\partial x_{k} \partial x_{p}}-\frac{\partial^{2} u_{i}}{\partial t^{2}}=0 \quad(i=1,2,3) .
$$

Они допускают решения с разрывными производными от компонент $u_{i}$ вектора перемещений по независимой переменной $x_{k}$ и времени $t$. В (6) постоянные коэффициенты $c_{i k, p q}$ представляют собой параметры упругой породы, $\rho$ - ее плотность.

Модуль фазовой скорости $v$ фронта и вектор поляризации $\vec{A}$ монохроматической волны $\vec{u}=\vec{A} \exp [i k(\vec{n} \cdot \vec{r}-v t)]$ определяются как собственные числа и собственные векторы вытекающего из (6) характеристического уравнения 


$$
\left|\sum_{k, p=1}^{3} \frac{c_{i k, p q}}{\rho} n_{k} n_{p}-\mathrm{v}^{2} \delta_{i k}\right|=0 .
$$

Три положительных собственных числа $v^{(1)}(\vec{n})>v^{(2)}(\vec{n}) \geq v^{(3)}(\vec{n})>0$ для любого направления нормали к фронту $\vec{n}$ определяют фразовые скорости фронтов для каждого из трех видов поляризации разрывных волн (одной квазипродольной и двух квазипоперечных).

Геометрическое трансформирование фронта волны во времени описывается соотношением (8)

$$
\tau\left(x_{1}, x_{2}, x_{3}\right)-t=0 .
$$

Используемую здесь фуннцию $\tau$ получаем из уравнения

$$
\sum_{i, k, p, q=1}^{3} \frac{c_{i k, p q}}{\rho} \frac{\partial \tau}{\partial x_{k}} \frac{\partial \tau}{\partial x_{p}} A_{q}^{(r)} A_{i}^{(r)}=1,
$$

являющегося обобщенным уравнением пути, пройденного волной (3), на случай однородной анизотропной среды [10].

Методом характеристик уравнение (9) приводится к системе обыкновенных диффференциальных уравнений

$$
\frac{d x_{k}}{d \tau}=\xi_{k}=\frac{1}{\rho_{i, p, q=1}} \sum_{i k, p q}^{3} p_{p} A_{q}^{(r)} A_{i}^{(r)} ; \frac{d p_{k}}{d \tau}=0 \quad(k=1,2,3) .
$$

Здесь $p_{k}=\partial \tau / \partial x_{k}=n_{k} / \mathrm{v}^{(\mathrm{r})}-$ компоненты вектора рефракции $\vec{p} ; \xi_{k}-$ компоненты вектора лучевой скорости $\vec{\xi}^{(r)}\left(\vec{n}, x_{k}\right)$, по направлению которого движется волна.

Найденные из (10) векторы $\vec{p}, \vec{\xi}^{(r)}$ определяют направление луча, вдоль которого движется волна.

Интенсивность волнового поля определяется в нулевом приближении $[4,5,7]$. Для этого достаточно решить только первое уравнение переноса вида (4). Для анизотропных однородных сред его решение приводится к равенству, позволяющему выражать разрыв этих производных через начальные условия и величину расхождения лучей в рассматриваемой точке лучевой трубки [10].

При изучении взаимодействия ударной волны с границей раздела $G$ двух анизотропных упругих сред с отличающимися механическими свойствами необходимо решить две задачи, первая из которых является кинематической, другая - динамической. Первая задача сводится к конструированию поверхностей фрронтов преломленных и отраженных квазипродольных и квазипоперечных разрывных волн, вторая - к определению разрывов производных на этих поверхностях. При постановке этих задач используется локально плоский подход [10], согласно кото- 
рому в малой окрестности точки взаимодействия падающей волны с поверхностью $G$ поверхности всех фрронтов (как и сама поверхность $G$ ) считаются локально плоскими. Основываясь на этом подходе, можно определить направления лучей сформировавшихся волн, пользуясь уравнениями Снеллиуса.

Для изучения динамических явлений около горных выработок можно использовать постановки и математический аппарат лучевой теории, с помощью которой исследуется взаимодействие ударных волн с горными выработками и включениями различных очертаний. Алгоритмичность разработанных методов позволяет с помощью вычислительной техники быстро оценить состояние устойчивости горной выработки и прогнозировать ее динамическое поведение.

При компьютерном моделировании динамических явлений в окрестности шахтных выработок под действием взрывных воздействий и горных ударов необходимо решать две задачи механики горных пород. Первая заключается в построении полей напряжений и деформаций под действием сил гравитации во всей области поперечного сечения выработки, подлежащей анализу. Задача статики решается с помощью метода конечных элементов по специально разработанной программе. Она реализуется решением системы линейных алгебраических уравнений $[K]\{u\}=\{f\}$ для конечноэлементной модели. Здесь $[K]-$ матрица жесткости упругой среды, генерируемая автоматически программным комплексом на основе исходных данных о геометрии горной выработки, физических свойствах породы и массовых силах $\{f\}$ (силах тяжести).

По найденному значению вектора $\{u\}$ подсчитываются компоненты тензора статических напряжений $\sigma^{c}$ породы. После этого осуществляется переход к постановке и решению задачи о взаимодействии ударной волны с граничной поверхностью выработки.

Алгоритм решения конкретных задач. Для анизотропных упругих горных пород уравнения Снеллиуса являются существенно нелинейными [8] и для их решения разработан специальный алгоритм, основанный на совместном применении метода Ньютона и метода продолжения по параметру. В соответствии с ним в окрестности некоторого известного $n$-го состояния углу падения $\Theta^{(n)}$ дается малое приращение $\Delta \Theta^{(n)}$ и вычисляются малые приращения углов остальных волн

$$
\begin{gathered}
\Delta \Theta_{(1+)}^{(V)} \approx \frac{\sin \Theta_{(1+)}^{(V)} \partial V_{(1-)}^{(1)} / \partial \Theta_{(1+)}^{(V)}-\cos \Theta_{(1+)}^{(V)} V_{(1+)}^{(1)}}{\sin \Theta_{(1+)}^{(V)} \partial V_{(1+)}^{(V)} / \partial \Theta_{(1+)}^{(V)}-\cos \Theta_{(1-)}^{(1)} V_{(1-)}^{(1)}} \Delta \Theta_{(1-)}^{(1)}- \\
-\sin \Theta_{(1-)}^{(1)} V_{(1+)}^{(V)}+\sin \Theta_{(1+)}^{(V)} V_{(1-)}^{(1)}
\end{gathered}
$$

Формула (11) позволяет подсчитать приращения углов отражения и преломления, соответствующих заданному приращению $\Delta \Theta_{(1-)}^{(1)}$ угла 
падения и построить лучи соответствующих волн, отходящих от границы горной выработки $G^{1}$. После этого можно вычислить значения разрывов производных функций перемещений на поверхностях сформировавшихся отраженных и преломленных волн. Для этого используются условия непрерывности на поверхности $G^{1}$. Например, на площадке $x_{2}=$ const поверхности $G^{1}$ эти уравнения имеют вид (12)

$$
\left.\left(\vec{u}_{(1)}-\vec{u}_{(2)}\right)\right|_{G 1}=0 ;\left.\quad\left(\vec{\sigma}_{2(1)}-\vec{\sigma}_{2(2)}\right)\right|_{G 1}=0
$$

где $\vec{u}_{(1)}, \vec{u}_{(2)}$ - векторы перемещений сред $\overline{\mathrm{I}}$ и $\overline{\mathrm{II}}$ на поверхности контакта $G^{1} ; \vec{\sigma}_{2(1)}, \vec{\sigma}_{2(2)}$ - векторы напряжений на площадке $x_{2}=$ const сред $\underline{\bar{I}}$ и $\underline{\overline{I I}}$.

$\mathrm{C}$ помощью разработанной методики решены задачи о напряженнодеформированном состоянии горного массива около протяженных выработок различного поперечного сечения в трансверсально-изотропных упругих горных породах.

Численные примеры. Предложенная теория была использована для исследования явлений взаимодействия взрывных плоских волн с эллиптическими выработками, расположенными на глубине $600 \mathrm{M}$ в трансверсально-изотропных упругих горных породах со следующими параметрами: $\lambda=2,972 \cdot 10^{10} \Pi a ; \mu=1,906 \cdot 10^{10} \Pi a ; l=0,1 \quad \lambda ; \quad m=0,2 \mu$; $p=0,4 \cdot(\lambda+2 \mu) ; \rho=1,85 \cdot 10^{3} \kappa 2 / \mathrm{m}^{3}$.

Результаты расчета для случая, когда поверхность выработки свободна от напряжений и связей, приведены на рис. 1 для динамических напряжений $\sigma_{x}(a)$ и для напряжений $\sigma_{y}(\sigma)$ (кривые 1$)$.
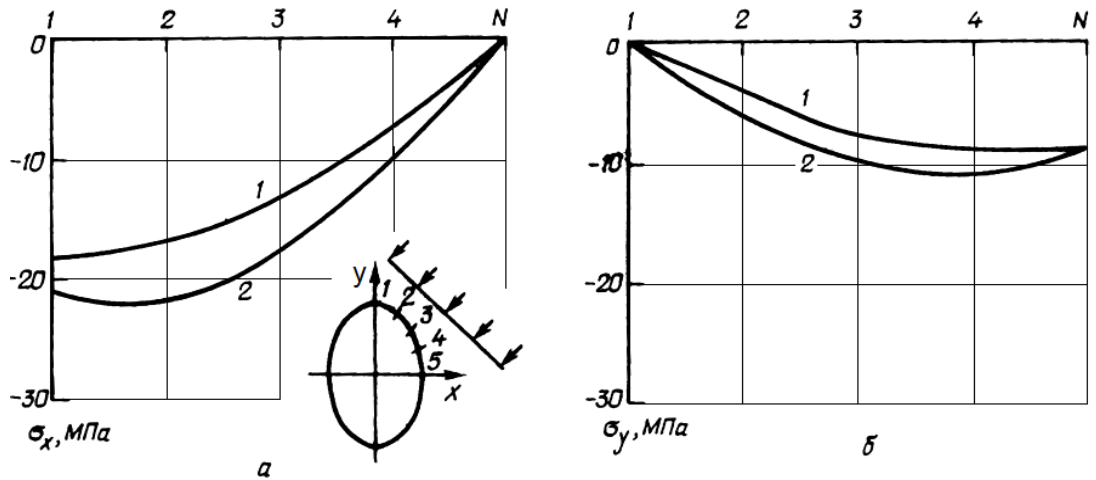

Рис. 1 - Распределение компонентов тензора напряжений в первом квадранте горной эллиптической выработки

В выработке эллиптического сечения при падении на нее фронта плоской взрывной волны в первом квадранте под углом 45 поля напряжений имеют относительно сглаженный характер (рис. 1). Здесь 
точка 1 контура лежит на вертикальной оси, точка 5 - на горизонтальной, точки 2, 3, 4 - между ними. Полуоси эллипса равны 1 и 1,5 м. Как следует из рис. 1,a, наибольшие суммарные напряжения $\sigma_{x}$ (кривая 2) реализуются в точке 2. Суммарные напряжения $\sigma_{y}$ в выработке эллиптического сечения имеют вид, изображённый на рис. 1,б (кривая 2).

На основе решений указанной выше задачи вычисляются суммарные компоненты тензора напряжений в наиболее напряженных зонах в окрестности поверхности выработки и определяются критические состояния породы. Они определяются согласно разработанному критерию динамической устойчивости выработки [2], в соответствии с которым критическое состояние наступает, когда суммарное статическое $\left(\sigma^{c}\right)$ и динамическое $\left(\sigma^{\partial}\right)$ напряжения достигают предельного значения $[\sigma]: \sigma=\left(\sigma^{c}+\sigma^{\partial}\right)=[\sigma] ; \sigma_{i}^{c}+\sigma_{i}^{\partial}=\sigma_{i}^{S}$,

$$
|\sigma|=\sqrt{\frac{1}{2}\left[\left(\sigma_{1}^{S}-\sigma_{2}^{s}\right)^{2}+\left(\sigma_{2}^{S}-\sigma_{3}^{s}\right)^{2}+\left(\sigma_{3}^{S}-\sigma_{2}^{s}\right)^{2}\right]} .
$$

На рис. 2 показано распределение напряжений по Мизесу в окрестности свободной выработки эллипсоидального очертания при выполнении условий (13).

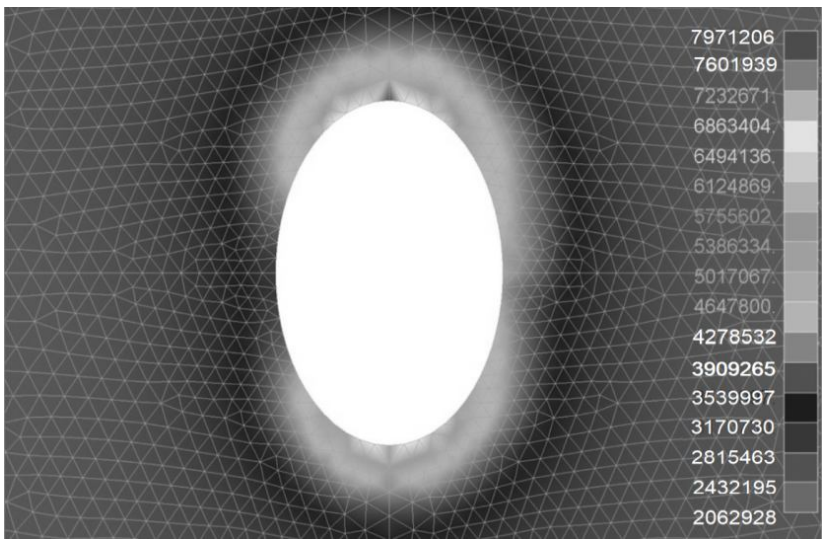

Рис. 2 - Распределение напряжений по Мизесу (Па) в окрестности горной выработки

Для данной задачи статические напряжения определялись с помощью метода конечных элементов, а динамическая составляющая рассчитывалась лучевым методом. Результаты этих расчетов хорошо согласуются с данными, приведенными на рис. 1.

Выводы. Анализируя полученные численные результаты, можно заключить, что при проектировании креплений горных выработок в шахтах, опасных по горным ударам и при ведении технологических взрывных работ, необходимо вводить соответствующий динамический коэффрициент. 


\section{БИБЛИОГРАФИЧЕСКИЕ ССЫЛКИ}

1. Арнольд В. И. Особенности каустик и волновых фронтов. М.: Фазис, 1996. 334 с.

2. Барановский 3., Кравец В. Г., Луговой П. З. Об устойчивости горных выработок при действии статических и динамических нагрузок // Форум гірників: Матеріали міжнарод. конф. - 2006. - Д/: Нац. гірн. ун-т. 2006. С. 33-40.

3. Бленд Д. Нелинейная динамическая теория упругости. М.: Мир, 1972. 183 с.

4. Гуляев В. И., Иванченко Г. М. Дифракция плоской разрывной волны в слоистой анизотропной упругой среде // Механика композитных материалов. 2003. № 1. С. 39-52.

5. Гуляев В. И., Луговой П. З., Иванченко Г. М. Яковенко Е. В. Дифракция ударной волны на криволинейной поверхности раздела трансверсально-изотропных упругих сред // Прикл. математика и механика. 2000. 64, № 3. С. 394-402.

6. Кравцов Ю. А., Орлов Ю. И. Геометрическая оптика неоднородных сред. М.: Наука, 1980. 304 с.

7. Луговой П. З., Гуляев В. И., Крицкий В. Б., Иванченко Г. М. Отражение и преломление плоских разрывных волн параболоидными поверхностями раздела анизотропных упругих сред // Геофизический журнал. 2005. Т. 27. № 3. С. 418-426.

8. Новацкий В. К. Волновые задачи теории пластичности. М.:Мир, 1978. 307 с.

9. Петрашень Г. И. Распространение волн в анизотропных упругих средах. Л.: Наука, 1980. 280 с.

10. Подильчук Ю. Н., Рубцов Ю. К. Лучевые методы в теории распространения и рассеяния волн. К.: Наукова думка, 1988. 220 с.

11. Gulyayev V. I., Ivanchenko G. M. Discontinuous wave interaction with interfaces between anisotropic elastic media // Int. J. Solids and Struct. 2006. No 43. P. 74-90.

12. Gulyayev V. I., Lugovoyy P. Z., Ivanchenko G. M. Discontinuous wave fronts propagation in anisotropic layered media // Int. J. Solids and Struct. 2003. No 40. P. 237-247.

13. Gulyaev V. I., Lugovoi P. Z., Ivanchenko G. M. Focusing and Scattering the Nonstationary Wave by the Free Surface of an Anisotropic Elastic Medium // Int. Appl. Mech. 2003. 39, No 7. P. 822-827.

14. Lugovoy P. Z., Guliaev V. I. Propagation of shock wave fronts in anisotropic layered media. CP505, Shock Compression of Condensed Matter - 1999 / Edit. by M. D. Furnish, L. C. Chhabildas and R.S.Nixon // Proc. Conf. of the Amer. Phys. Soc., Snowbird, Utah, USA, 1999. P. 1287-1290.

15. Rubtsov Yu. K., Borisov E. N. Analysis of the Nonstationary Spatial Propagation of Elastic Waves from Cavities Subject to Mechanical and Thermal Loads // Int. Appl. Mech. 2006. 42, No 8. P. 913-921.

\section{УДК 539.3}

П. З. Луговий, д-р техн. наук, Т. В. Гребенюк, канд. техн. наук ВЗАЄМОДІЯ УДАРНИХ ХВИЛЬ 3 ГІРНИЧИМИ ВИРОБКАМИ

Теоретичне моделювання взаємодії ударних хвиль 3 гірничими виробками вельми актуально в гірничій справі. Особлива роль в задачах дослідження дії ударних хвиль, викликаних технологічними вибухами або гірськими ударами, належить променевому методу. 3 його допомогою досліджено напружений стан гірських виробок при дії на них вибухових хвиль. Запропоновано динамічний критерій міцності для визначення стійкості гірничих виробок. На конкретному прикладі показана ефективність розробленої методики.

Ключові слова: гірничі виробки, ударні хвилі, променевий метод, міцнісна стійкість, чисельні результати. 
P. Z. Lugovoi, Dr. Sci. (Tech.), T. V. Hrebeniuk, PhD (Tech.)

\section{INTERACTING SHOCK WAVES WITH MINING WORKINGS}

Theoretical modeling of the interaction of shock waves with mine workings is very important in mining. A special role in the problems of studying the action of shock waves caused by technological explosions or rock blows belongs to the ray method. With its help, the stress state of the mine workings under the influence of explosive waves is studied. A dynamic strength criterion is proposed for determining the stability of mine workings. On a specific example, the effectiveness of the developed methodology is shown.

Keywords: mine workings, shock waves, ray method, strength stability, numerical results.

The tasks of theoretical modeling of the phenomena of propagation of shock waves are very relevant in mining when determining the strength and stability of rocks and supports in the vicinity of mine workings under the influence of explosions and rock blows. At the present stage of development of the coal industry, the problem of taking into account dynamic factors in the design and operation of workings of various profiles has become very acute. The dynamic research method is more general than the static, although more complex. To study dynamic phenomena near mine workings, one can use the formulation and mathematical apparatus of the ray theory, with the help of which the interaction of shock waves with mine workings and inclusions of various shapes is studied. Algorithmicity of the developed methods allows using computer technology to quickly assess the state of stability of a mine working and to predict its dynamic behavior.

In this work, when computer modeling the stability of rocks in the vicinity of mine workings under the action of shock waves, taking into account the presence of preliminary stresses of rock pressure, two problems of rock mechanics are solved. The first is the construction of stress fields under the action of gravitational forces in the entire area of the cross-section of the mine. The task of statics is solved using the finite element method according to a specially developed program. After that, a transition is made to the formulation and solution of the problem of the interaction of a shock wave with the boundary surface of a mine. At this stage, the evolutionary fronts of shock waves are constructed by ray methods and the values of shock pulses on their surfaces are calculated. With the help of the developed methodology, the problems of dynamics on the stress state of extended mine workings of various cross-sections are solved. As a specific example, the development of an elliptical section at a depth of 600 meters when a plane shock wave is incident on it is considered. The semi-axes of the ellipse are 1 and $1.5 \mathrm{~m}$. For this problem, the static stresses were determined using the finite element method and mathematical support, and the vicinity of the surface of the excavation are calculated and critical rock conditions are determined. They are determined according to the criterion of dynamic stability of the mine, developed by the authors, in accordance with which the dangerous currents for the destruction of the elliptical mine are determined. A critical 
state occurs when the total static and dynamic stresses reach the limit value. The results can be used to calculate the support of an elliptical mine.

\section{REFERENCES}

1. Arnold V. I. Features of caustics and wave fronts. Moscow: Fazis, 1996. 334 p. (in Russian).

2. Baranovsky Z., Kravets V. G., Lugovoi P. Z. On the stability of mine workings under the action of static and dynamic loads // Forum girnikiv: Materiali mizhnarod. conf. 2006. Dnipropetrovsk: National. hirn. Univ., 2006. P. 33-40. (in Russian). sian).

3. Blend D. Nonlinear dynamic theory of elasticity. Moscow: Mir, 1972. 183p. (in Rus-

4. Gulyaev V. I., Ivanchenko G. M. Diffraction of a plane shock wave in a layered anisotropic elastic medium // Mechanics of composite materials. 2003. No. 1. P. 39-52. (in Russian).

5. Gulyaev V. I., Lugovoi P. Z., Ivanchenko G. M. Yakovenko E. V. Shock wave diffraction on a curved interface between transversely isotropic elastic media // Prikl. mathematics and mechanics. 2000. 64, No. 3. P. 394-402. (in Russian).

6. Kravtsov Yu. A., Orlov Yu. I. Geometric optics of heterogeneous media. Moscow: Nauka, 1980. 304 p. (in Russian).

7. Lugovoi P. Z., Gulyaev V. I., Kritsky V. B., Ivanchenko G. M. Reflection and refraction of plane discontinuous waves by paraboloidal interfaces between anisotropic elastic media // Geophysical Journal. 2005. Vol. 27. No. 3. P. 418-426. (in Russian).

8. Novatsky V. K. Wave problems of the theory of plasticity. Moscow: Mir, 1978. 307 p. (in Russian).

9. Petrashen G. I. Wave propagation in anisotropic elastic media. Leningrad: Nauka, 1980. 280 p. (in Russian).

10. Podilchuk Yu. N., Rubtsov Yu. K. Radiation methods in the theory of wave propagation and scattering. Kyiv: Naukova Dumka, 1988. 220 p. (in Russian).

11. Gulyayev V. I., Ivanchenko G. M. Discontinuous wave interaction with interfaces between anisotropic elastic media // Int. J. Solids and Struct. 2006. No 43. P. 74-90.

12. Gulyayev V. I., Lugovoyy P. Z., Ivanchenko G. M. Discontinuous wave fronts propagation in anisotropic layered media // Int. J. Solids and Struct. 2003. 40. P. 237-247.

13. Gulyaev V. I., Lugovoi P. Z., Ivanchenko G. M. Focusing and Scattering the Nonstationary Wave by the Free Surface of an Anisotropic Elastic Medium // Int. Appl. Mech. 2003. 39, No 7. P. 822-827.

14. Lugovoy P. Z., Guliaev V. I. Propagation of shock wave fronts in anisotropic layered media. CP505, Shock Compression of Condensed Matter - 1999 / Edit. by M. D. Furnish, L.C.Chhabildas and R.S.Nixon // Proc. Conf. of the Amer. Phys. Soc., Snowbird, Utah, USA, 1999. P. 1287-1290.

15. Rubtsov Yu. K., Borisov E. N. Analysis of the Nonstationary Spatial Propagation of Elastic Waves from Cavities Subject to Mechanical and Thermal Loads // Int. Appl. Mech. 2006. 42, N 8. P. 913-921.

${ }^{1}$ Інститут механіки ім. С.П. Тимошенка

НАН України,

${ }^{2}$ Національний технічний університет

України «КПІ ім. Ігоря Сікорського», Київ, Україна

Надійшла до редколеаії 02.11.2019 